\title{
DEVELOPMENT OF CONTEXTUAL TEACHING-BASED E- MODULES IN GRADE V ELEMENTARY SCHOOL LEARNING
}

\author{
Submitted: \\ 24 Desember 2021 \\ Accepted: \\ 18 Januari 2021 \\ Published: \\ 31 Januari 2022
}

\author{
Mega Prasrihamni' ${ }^{1}$, Arita Marini $^{2}$, Herlina $^{3}$ \\ megaprasrihamni@univpgri-palembang.ac.id ${ }^{1}$ \\ ,aritamarini@unj.ac.id ${ }^{2}$, herlina@unj.ac.id ${ }^{3}$ \\ Universitas PGRI Palembang ${ }^{1}$ \\ Universitas Negeri Jakarta ${ }^{2,3}$
}

*Corresponding Author

\begin{abstract}
The purpose of this study was to determine the development of e-modules based on Contextual Teaching in the fifth grade of elementary school learning. This research method uses research and development methods with the ADDIE approach. This research method uses research and development methods with the limits of expert judgment and practicality. Expert assessment is carried out on media, language, and material experts, while practicality with teachers and students. Data collection techniques use documentation and questionnaires, while data analysis techniques use percentages. Based on the results of the study showed that the EModule Based on Contextual Teaching with an average of 3.70. Thus, it can be concluded that the development of Contextual Teaching-based E-modules in fifth grade elementary school learning is included in the valid or feasible category. From the results of the small group test and large group test, an average of 3.645 was obtained. Thus, it can be concluded that the feasibility of Contextual Teaching-based E-modules in class $\mathrm{V}$ elementary school learning is included in the practical or feasible category.
\end{abstract}

Keywords: E-Module, Contextual Teaching.

\section{PENDAHULUAN}

Saat ini dunia dihadapkan dengan wabah penyakit yang disebabkan oleh virus yang bernama Coronavirus Disease atau dikenal dengan istilah Covid-19. Pada tanggal 30 Januari 2020 WHO menetapkan sebagai kedaruratan kesehatan masyarakat yang meresahkan dunia. Dampak Covid-19 di Indonesia saat ini cukup besar bagi seluruh masyarakat. Dengan terus melonjaknya kasus positif Covid-19 di Indonesia mendesak pemerintah untuk segara menangani pandemi Covid-19 dengan membuat berbagai kebijakan seperti menerapkan phsycal distancing, PSBB (Pembatasan Sosial Berskala Besar), dan lockdown. Dengan adanya kebijakan tersebut dampak yang besar diberbagai 
aspek kehidupan, tidak terkecuali pada pendidikan sehingga mengharuskan melakukan pembelajaran secara daring.

Kuntarto (2017:99-110) menyatakan bahwa pembelajaran daring adalah pembelajaran yang dalam proses pembelajarannya menggunakan teknologi multimedia, kelas virtual, video, teks online animasi, email, pesan suara, telepon konferensi, dan video streaming online. Menurut Enriques (2018) dalam pembelajaran daring guru dan peserta didik melakukan pembelajaran bersama, waktu yang sama, dengan menggunakan berbagai aplikasi, seperti Whatsapp, Edmodo, Telegram, Zoom Meeting, maupun aplikasi lainnya.

Lefudin (2014: 45) pembelajaran merupakan proses interaksi antara peserta didik dengan pendidik dan sumber belajar pada lingkungan belajar. Pembelajaran sebagai proses belajar yang dibangun oleh guru untuk mengembangkan kreatifitas berpikir yang dapat meningkatkan kemampuan berpikir siswa serta dapat meningkatkan kemampuan mengkontruksi pengetahuan baru sebagai upaya peningkatan penguasaan yang baik terhadap materi pembelajaran.

Bahan ajar yang cocok digunakan dalam pembelajaran daring salah satunya yaitu E-modul. Modul elektronik (E-modul) merupakan pengembangan modul cetak dalam bentuk digital yang banyak mengadaptasi dari modul cetak. Menurut Herawati (2018) merupakan media inovatif yang dapat meningkatkan minat siswa dalam belajar dan mengajar. Modul maupun E-modul memiliki komponen yang sama. Jannah (2020) menyatakan bahwa komponen E-modul meliputi: petunjuk/pedoman, lembar kegiatan, latihan soal, kunci jawaban, lembar tes dan kunci jawaban. E-modul juga memiliki elemen-elemen yang harus dipenuhi. Elemen penyusunan E-modul yang harus dipenuhi yaitu: konsistensi, layout, organisasi, daya tarik, bentuk dan ukuran huruf, dan penggunaan ruang/spasi kosong. Dari beberapa pendapat tersebut dapat ditarik kesimpulan bahwa E-modul adalah seperangkat media pengajaran digital atau non cetak yang disusun secara sistematis yang digunakan untuk keperluan belajar secara mandiri. Sehingga menuntut peserta didik untuk belajar memecahkan masalah dengan caranya sendiri.

E-modul yang dirancang perlu disesuaikan dengan pengalaman dalam kehidupan sehari-hari sehingga tujuan pembelajaran dapat tercapai. Pendekatan yang dalam pembelajarannya mengupayakan agar siswa dapat menggali kemampuan yang 
dimilikinya dengan memahami konsep- konsep yang berada dilingkungan sekitar mereka dalam dunia nyata disebut Contextual Teaching. E- modul yang mengakomodasi kebutuhan siswa dan layak digunakan dengan memperhatikan kemenarikan, kemudahan, dan kebermanfaatannya adalah E-modul berbasis Contextual Teaching, karena mampu beradaptasi dengan kurikulum apa saja termasuk dalam implementasi kurikulum 2013. Komalasari (2013: 7) berpendapat bahwa Contextual Teaching adalah pembelajaran yang mengaitkan materi yang dipelajari dengan kehidupan nyata siswa sehari-hari, baik dalam lingkungan keluarga, sekolah, masyarakat maupun warga negara dengan tujuan untuk menemukan makna materi tersebut.

Berdasarkan hasil wawancara peneliti dengan wali kelas V di SD 91 Palembang, pembelajaran selama covid-19 ini cenderung monoton karena siswa hanya dikirim tugas melalui Whatsapp dan kurangnya sumber belajar. Siswa terkadang merasa jenuh dan kesulitan memahami pembelajaran. Sehingga semangat belajar siswa pun rendah. Menurut wali kelas V di SD Negeri 91 Palembang, mayoritas siswanya sudah memiliki handphone untuk menunjang proses pembelajaran. Lebih lanjut berdasarkan analisis kebutuhan, tampak bahwa guru kelas $\mathrm{V}$ belum sepenuhnya memanfaatkan media dan bahan ajar berbasis teknologi. Guru juga belum memproduksi media dan bahan ajar berbasis teknologi seperti E-modul. Berdasarkan permasalahan tersebut salah satu solusinya adalah memaksimalkan sarana teknologi yaitu melalui pengembangan bahan ajar berupa E-modul sebagai sumber belajar siswa agar dapat memotivasi siswa sehingga meningkatkan semangat belajar siswa. Selain itu sudah banyak penelitian yang membahas tentang pengembangan E-modul salah satunya seperti penelitian terdahulu yang dilakukan oleh Heni Widya Ayu Isnia, dkk. (2020) menunjukkan bahwa E-modul cocok diterapkan dalam proses pembelajaran.

Alasan peneliti memilih pengembangan E-modul dan bukan media lain karena Emodul dapat memfasilitasi siswa karena dilengkapi dengan petunjuk untuk belajar secara mandiri, siswa dapat belajar sesuai dengan kemampuannya dan dapat memenuhi seluruh kompetensi yang harus dikuasai oleh siswa. Didalam E-modul ini berisi teks materi, gambar serta video. Manfaat penggunaan media E-modul sebagai sumber belajar dalam proses pembelajaran antara lain, siswa dapat menambah dan memperluas pengetahuannya. Siswa dapat memperluas pengetahuan dengan mempelajari materi- 
materi tambahan yang disajikan didalam E-modul. Dengan demikian, media pembelajaran E-modul dapat memotivasi kemandirian belajar siswa. Berdasarkan uraian di atas maka penelitiakan melakukan penelitian mengenai "Pengembangan E-

\section{Modul Berbasis Contextual Teaching Pada Pembelajaran Kelas V SekolahDasar".}

Modul ini merupakan salah satu bahan ajar yang mampu meningkatkan efektivitas dan efisiensi pembelajaran disekolah. Menurut Purwanto, dkk. (2007: 9) modul merupakan bahan/ sumber belajar yang dirancang secara sistematis berdasarkan kurikulum tertentu dan dikemas dalam bentuk satuan pembelajaran terkecil dan memungkinkan dipelajari secara mandiri dalam satuan waktu tertentu.Tujuan disusunnya modul ialah agar peserta dapat menguasai kompetensi yang diajarkan kegiatan pembelajaran dengan sebaik-baiknya. Bagi guru, modul juga menjadi acuan dalam menyajikan dan memberikan materi selama diklat atau kegiatan pembelajaran berlangsung.Fungsi modul adalah sebagai bahan belajar yang digunakan dalam kegiatan pembelajaran pesertadidik.

Selanjutnya, Majid (2013: 176) menyatakan bahwa modul merupakan bagian dari jenis-jenis bahan ajar yang digunakan dalam membantu proses pembelajaran bagi peserta didik. Modul dapat diartikan sebuah buku yang dirancang dengan tujuan agar peserta didik dapat belajar secara mandiri tanpa atau dengan bimbingan pendidik.Dengan modul peserta didik dapat belajar lebih terarah dan sistematis secara mandiri.

Menurut Prastowo (2011: 105) modul merupakan program belajar mengajar yang dapat dipelajari oleh peserta didik dengan bantuan yang minimal dari guru atau dosen pembimbing, meliputi perencanaan tujuan yang akan dicapai secara jelas penyediaan materi pembelajaran alat yang dibutuhkan dan alat untuk penilai, serta pengukuran keberhasilan peserta didik dalam penyelesaian pembelajaran.

Menurut Hamdani (2010: 219) modul adalah sarana pembelajaran dalam bentuk tertulis yang disusun secara sistematis, memuat materi pembelajaran, metode, tujuan pembelajaran berdasarkan kompetensi dasar atau indikator pencapaian kompetensi, petunjuk kegiatan belajar mandiri, dan memberikan kesempatan kepada siswa untuk menguji diri sendiri melalui latihan yang disajikan dalam modultersebut.

Daryanto (2013: 9) menyatakan modul adalah sebuah buku yang ditulis dengan tujuan agar siswa dapat belajar secara mandiri tanpa atau dengan bimbingan guru, 
sehingga modul berisi paling tidak tentang segala komponen dasar bahan ajar. Berdasarkan pendapat para ahli tersebut dapat disimpulkan bahwa modul merupakan salah satu program pengajaran mengenai suatu satuan bahasan yang sengaja disusun secara sistematis, operasional dan terarah untuk digunakan oleh peserta didik. Dengan tujuan agar peserta didik dapat menguasai kompetensi yang diajarkan dalam kegiatan pembelajaran dengan sebaik-baiknya.

Mustaji (2008: 30-32) mengemukakan unsur-unsur modul secara rinci sebagai berikut:

1. Rumusan Tujuan Instruksional

Tujuan tersebut dirumuskan dalam bentuk tingkah laku yang diharapkan dari siswa setelah mereka mempelajari modul.

2. Petunjuk Guru

Memuat penjelasan bagi guru tentang pengajaran agar dapat terlaksana dengan efisien, serta memberikan penjelasan tentang macam-macam kegiatan yang dilaksanakan dalam proses belajar, waktu untuk menyelesaikan modul, alat-alat dan sumber pelajaran, serta petunjuk evaluasi.

3. Lembar Kegiatan Siswa

Lembaran ini berisi materi-materi pelajaran yang harus dikuasai oleh siswa serta dicantumkan buku sumber yang harus dipelajari siswa untuk melengkapi materi.

4. Lembar Kerja Siswa

Lembar kerja ini merupakan pertanyaan-pertanyaan yang ada padalembar kegiatan yang harus dikerjakan siswa setelah mereka selesai menguasai materi.

5. Kunci Lembar Kerja

Siswa dapat mengoreksi sendiri jawabannya dengan menggunakan kunci lembar kerja setelah mereka berhasil mengerjakan lembar kerja

E-modul merupakan sarana pembelajaran yang berisi materi, metode, batasanbatasan dan cara mengevaluasi yang dirancang secara sistematis dan menarik untuk mencapai kompetensi yang diharapkan sesuai dengan tingkat kompleksitasnya secara elektronik bagian e-learning (Depdiknas, 2008). E-modul yang dirancang dalam bentuk digital dan sistematis dapat mendukung siswa agar dapat belajar mandiri. Hal tersebut membuat siswa dituntut untuk belajar memecahkan masalah dengan caranya sendiri. Emodul dapat diakses baik melalui laptop atau smartphone. Di Indonesia telepon seluler 
telah mengubah peta industri telekomunikasi. Dimana telepon yang dulunya merupakan barang mewah, sehingga hanya kelompok-kelompok yang bisa menikmatinya, sekarang dengan mudah mendapatkannya.

Menurut Solikin (2019: 190) E-modul merupakan bahan ajar yang bersifat self instructional yang memuat materi pembelajaran dengan tujuan agar peserta didik dapat mempelajari secara mandiri dan meningkatkan hasil belajar. Adapun beberapa kriteria yang harus dimuat dalam E-modul yaitu: petunjuk belajar, isi materi pembelajaran, kompetensi yang akan dicapai, latihan-latihan, petunjuk kerja (lembar kerja), evaluasi, informasi pendukung. Selanjutnya menurut Munadi (2013: 99) E-modul merupakan bahan ajar siswa untuk belajar mandiri dengan bantuan seminimal mungkin dari orang lain. Modul maupun E-modul memiliki komponen yang sama.

Nurul Latifah (2020) menyatakan bahwa modul elektronik atau E-modul merupakan sebuah bentuk penyajian bahan belajar mandiri yang disusun secara sistematis kedalam unit pembelajaran terkecil untuk mencapai tujuan pembelajaran tertentu yang disajikan ke dalam format elektronik yang di dalamnya terdapat animasi, audio, navigasi yang membuat pengguna lebih interaktif dengan program.E-modul dapat diimplementasikan sebagai sumber belajar mandiri yang dapat membantu siswa dalam meningkatkan kompetensi atau pemahaman secara kognitif yang dimilikinya serta tidak bergantung lagi pada satu-satunya sumber informasi. E-modul juga dapat digunakan di mana saja, sehingga lebih praktis untuk dibawa. Karena E-modul merupakan penggabungan dari media cetak dan komputer, maka E-modul dapat menyajikan informasi secara terstruktur, menarik serta memiliki tingkat interaktifitas yang tinggi. Selain itu, proses pembelajaran tidak lagi bergantung pada instruktur sebagai satu-satunya sumber informasi.

Berdasarkan pendapat para ahli tersebut dapat disimpulkan bahwa E-modul merupakan modifikasi dari modul konvensional dengan pemanfaatan teknologi informasi, sehingga modul dapat menarik dan interaktif. E-modul ialah bahan ajar yang dapat dirancang oleh guru dengan mempertimbangkan siswa dan metode mengajar pilihan guru yang berisi kumpulan materi pelajaran yang digunakan oleh peserta didik untuk belajar secara mandiri.

Menurut Murtono (2017: 116) mengemukakan bahwa pembelajaran kontekstual dapat terjadi siswa mampu menerapkan dari hasil mengalami apa yang sedang 
diacarkan dengan mengacu yang terjadi pada dunia nyata yang berhubungan dengan peran dan tanggung jawab mereka sebagai anggota keluarga, masyarakat, siswa, warga negara, dll. Oleh sebab itu pembelajaran kontekstual dapat berlangsung dalam berbagai konteks kehidupan, baik disekolah, rumah, maupun lingkungan masyarakat.

Selanjutnya, Soimin (2014: 41) menyatakan bahwa Contextual Teaching atau biasa disebut pembelajaran kontekstual adalah merupakan suatu konsep pembelajaran yang holistik, dimana materi pelajaran dikaitkan dengan lingkungan sekitar atau konteks kehidupan sehari-hari baik sosial, budaya, kulltur, maupun kehidupan pribadi peserta didik sehingga akan menghasilkan pembelajaran yangbermakna dan peserta didik dapat memiliki pengetahuan maupun keterampilan yang dapat diterapkan pada berbagai permasalahan.

Menurut Sanjaya (2006: 255) Contextual Teaching adalah suatu pendekatan pembelajaran yang menekankan proses keterlibatan siswa secara penuh untuk dapat menemukan materi yang dipelajari dan menghubungkannya dengan situasi kehidupan nyata sehingga mendorong siswa untuk dapat menerapkannya dalam kehidupan mereka.Berdasarkan pendapat para ahli diatas, dapat disimpulkan bahwa Contextual Teaching adalah pendekatan pembelajaran yang dapat membantu guru mengaitkan antara materi yang diajarkan dengan kehidupan sehari-hari siswa, dan mendorong siswa menghubungkan antara pengetahuan atau materi yang telah diterima dengan menerapkannya dalam kehidupan sehari-hari siswa.

Menurut Komalasari (2013: 7) karakteristik pembelajaran kontekstual meliputi pembelajaran yang menerapkan beberapa konsep, yaitu:

1.) Keterkaitan (relating), pembelajaran yang menerapkan konsep keterkaitan, yaitu pembelajaran yang memiliki keterkaitan (relevansi) dengan bekal pengetahuan yang telah ada pada diri siswa dan dengan konteks pengalaman dalam kehidupan nyata siswa.

2.) Pengalaman langsung (experiencing), pembelajaran yang menerapkan konsep pengalaman langsung, yaitu proses yang memberikan kesempatan pada siswa untuk mengonstruksi pengetahuan dengan cara menemukan dan mengalami sendiri secara langsung.

3.) Aplikasi (applaying), pembelajaran yang menerapkan konsep aplikasi, yaitu proses pembelajaran yang menekankan pada penerapan fakta, konsep, prinsipdan 
prosedur yang dipelajari dalam situasi dan kontekslain yang berbeda, sehingga bermanfaat bagi kehidupan siswa.

4.) Kerja sama (cooperating), pembelajaran yang menggunakan konsep kerja sama, yaitu pembelajaran yang mendorong kerja sama di antara siswa, antara siswa dan guru, dan sumber belajar.

5.) Pengaturan diri (self-regulating), pembelajaran yang menggunakan konsep pengaturan diri, yaitu pembelajaran yang mendorong siswa untuk mengatur diri dan pembelajarannya secara mandiri.

6.) Asesmen autentik (authentic assessment), pembelajaran yang menerapkan konsep asesmen autentik adalah pembelajaran yang mengukur, memonitor dan menilai semua aspek hasil belajar, baik yang tampak sebagai hasil akhir dari suatu proses pembelajaran maupun berupa perubahan dan perkembangan aktivitas dan perolehan belajar selama proses pembelajaran didalam kelas ataupun diluar kelas.

Menurut Rusman (2013: 192) langkah-langkah pembelajaran Contextual Teaching antara lain:

1. Mengembangkan pemikiran bahwa anak akan belajar lebih bermakna dengan cara bekerja sendiri, menemukan sendiri dan mengkonstruksi sendiri pengetahuan dan keterampilan barunya

2. Melaksanakan sejauh mungkin kegiatan inquiry untuk semua topik

3. Mengembangkan sifat ingin tahu siswa dengan melalui memunculkan pertanyaanpertanyaan

4. Menciptakan masyarakat belajar

5. Menghadirkan model sebagai contoh belajar

6. Melakukan refleksi diakhir pertemuan

7. Melakukan penilaian secrara objektif, yaitu menilai kemampuan yang sebenarnya pada setiap siswa.

Menurut Rusman (2013: 193) terdapat tujuh prinsip dalam pembelajaran kontekstual antara lain, yaitu:

1. Konstruktivisme (constructivism), konstruktivisme merupakan landasan berpikir (filosofi) dalam Contextual Teaching, yaitu bahwa pengetahuan dibangun oleh manusia sedikit demi sedikit yang hasilnya diperluas melalui konteks yang 
terbatas. Pengetahuan bukanlah seperangkat fakta, konsep, atau kaidah yang siap untuk diambil dan diingat. Menusia harus membangun pengetahuan dan memberi makna melalui pengalaman yang nyata. manusia sedikit demi sedikit yang hasilnya diperluas melalui konteks yang terbatas. Pengetahuan bukanlah seperangkat fakta, konsep, atau kaidah yang siap untuk diambil dan diingat. Manusia harus membangun pengetahuan dan memberi makna melalui pengalaman yang nyata. Siswa harus mengkonstruksikan pengetahuan dibenak mereka sendiri. Esensi dari teori konstruktivis, yaitu ide bahwa siswa harus menemukan dan mentransformasikan suatu informasi kompleks ke situasi lain, dan apabila dikehendaki informasi itu menjadi milik mereka sendiri.

2. Menemukan (inquiry), inkuiri merupakan bagian inti dari kegiatan pembelajaran berbasis kontekstual. Pengetahuan dan keterampilan yang diperoleh siswa diharapkan bukan hasil mengingat seperangkat fakta-fakta, akan tetapi hasil dari menemukan sendiri.

3. Bertanya (questioning), pengetahuan yang dimiliki seseorang selalu bermula dari bertanya. Penerapan bertanya dalam Contextual Teaching harus difasilitasi oleh guru, kebiasaan siswa untuk bertanya atau kemampuan guru dalam menggunakan pertanyaan akan mendorong pada peningkatan kualitas dan produktivitas pembelajaran.

4. Masyarakat belajar (learning community), maksud dari masyarakat belajar, yaitu membiasakan siswa untuk melakukan kerja sama dan memanfaatkan sumber belajar dari teman-teman belajarnya. Hasil belajar yang diperoleh dari sharingantar teman, antar kelompok, dan antar yang tahu ke yang belum tahu. Diruang ini, dikelas ini, disekitar sini, juga orang-orang yang ada diluar sana, semua adalah anggota masyarakat-belajar.

5. Pemodelan (modelling), modelling adalah proses pembelajaran dengan memperagakan sesuatu sebagai contoh yang dapat ditiru oleh setiap siswa. Guru dapat menjadi model, misalnya memberi contoh cara mengerjakan sesuatu. Proses modelling tidak terbatas dari guru saja, akan tetapi dapat juga memanfaatkan siswa yang dianggap memiliki kemampuan.

6. Refleksi (reflaction), refleksi adalah cara berpikir tentang apa yang baru terjadi atau baru saja dipelajari. Pada saat refleksi, siswa diberi kesempatan untuk 
mencerna, menimbang, membandingkan, menghayati, dan melakukan diskusi dengan dirinya sendiri.

7. Penilaian sebenarnya (authentic assessment), penilaian autentik menilai pengetahuan dan keterampilan yang diperoleh siswa. Penilai tidak hanya guru, tetapi bisa juga teman atau orang lain.

Masalah pada penelitian ini adalah sebagai berikut: Bagaimanakah pengembangan E-modul berbasis Contextual Teaching pada pembelajaran kelas V Sekolah Dasar yang valid? Bagaimanakah kelayakan E-modul berbasis Contextual Teaching pada pembelajaran kelas V Sekolah Dasar?

Berdasarkan masalah di atas, tujuan dari penelitian ini adalah: Untuk mengetahui cara mengembangakan E-modul berbasis Contextual Teaching pada pembelajaran kelas V Sekolah Dasar yang valid. Untuk mengetahui kelayakan E-modul berbasis Contextual Teaching pada pembelajaran kelas V Sekolah Dasar.

\section{METODE}

Metode penelitian dan pengembangan (Research and Development). Sugiyono (2016: 297) menyatakan bahwa Research and Development adalah metode penelitian yang digunakan untuk menghasilkan produk tertentu dan menguji keefektifan produk. Research and Development bisa didefinisikan sebagai media penelitian yang secara sengaja, sistematis, bertujuan, atau diarahkan merumuskan, memperbaiki, mengembangkan, menghasilkan, menguji keefektifan produk, model, metode, strategi atau cara, jasa, prosedur tertentu yang lebih unggul, baru, efektif, efisien, produktif dan bermakna. Menurut Sugiyono (2019: 765-766) mengembangkan Instructional Design (Desain Pembelajaran) dengan pendekatan ADDIE, yang merupakan perpanjangan dari Analysis, Design, Development, Implementation dan Evalution. Analysis, berkaitan dengan kegiatan analisis terhadap situasi kerja dan lingkungan sehingga dapat ditemukan produk apa yang perlu dikembangkan. Design merupakan kegiatan perancangan produk sesuai dengan yang dibutuhkan. Development adalah kegiatan pembuatan dan pengujian produk. Evaluation adalah kegiatan menilai apakah setiap langkah kegiatan dan produk yang telah dibuat sesuai dengan spesifikasi atau belum. Pada pengembangan ini akan dilakukan sesuai dengan prosedur yang terdiri dari lima 
langkah. Kelima langkah tersebut adalah: Analysis (analisis), design (desain), development (pengembangan), implementation (implementasi), evaluation (evaluasi). Jenis dan Sumber Data Penelitian:

1. Wawancara

Menurut Sugiyono (2016: 137) wawancara digunakan sebagai teknik pengumpulan data apabila peneliti ingin melakukan studi pendahuluan untuk menemukan permasalahan yang diteliti. Wawancara yang dilakukan adalah wawancara tidak terstruktur dimana peneliti tidak menggunakan pedoman wawancara dan wawancara dilakukan untuk memperoleh informasi mengenai permasalahan dalam pembelajaran tematik.

2. Angket (Kuesioner)

Sugiyono (2016:142) menyatakan bahwa angket (kuesioner) adalah teknik pengumpulan data yang dilakukan dengan cara memberi seperangkat pertanyaan atau pernyataan tertulis kepada responden untuk dijawabnya. Kuesioner merupakan teknik pengumpulan yang efisien bila peneliti tahu dengan pasti variabel yang akan diukur dan tahu apa yang diharapkan dari responden. Selain itu, kuesioner juga cocok digunakan bila jumlah responden cukup besar dan tersebar diwilayah yang luas. Kuesioner dapat berupa pertanyaan atau pernyataan tertutup atau terbuka, dapat diberikan kepada responden secara langsung atau dikirim melalui pos atau internet. Bila penelitian dilakukan pada lingkup yang tidak terlalu luas, sehingga kuesioner dapat diantarkan langsung dalam waktu tidak terlalu lama, maka pengiriman angket kepada responden tidak perlu melalui pos. Dengan adanya kontak langsung antara peneliti dengan responden dengan sukarela akan memberikan data objektif data dan cepat.

3. Dokumentasi

Dokumentasi berfungsi sebagai data dalam bentuk fisik berupa dokumendokumen yang terkait dengan penelitian yang dilakukan diantaranya adalah prototipe, komentar atau saran dari validator, komentar atau saran dari pendidik, komentar atau saran dari siswa dan jawaban siswa.

4. ObjekPenelitian

Objek dalam penelitian ini adalah kualitas E-modul berbasis Contextual Teaching pada pembelajaran tematik. 
Teknik analisis data dilakukan untuk mendapatkan media pembelajaran berupa E-modul berkualitas yang memenuhi kriteria kevalidan, dan kepraktisan. Langkah-langkah dalam menganalisis kriteria E-modul yang dikembangkan adalah sebagai berikut:

1. Analisis Kevalidan

Berdasarkan data validasi penilaian media oleh ahli media, ahli bahasa, dan ahli materi dapat diketahui kevalidan media dengan langkah-langkah sebagai berikut: data kuantitatif didapatkan dari ahli media, ahli materi, ahli bahasa dan pendidik yang disusun dengan skala Likert, akan dihitung skor rata-rata lembar validasi ahli media, ahli materi, ahli bahasa dan pendidik, kriteria kevalidan E-modul. Langkah pertama adalah memberikan skor pada tiap kriteria ketentuan pada tabel sebagai berikut:

Tabel 1. Pedoman Skor Penilaian

\begin{tabular}{|l|c|}
\hline Kriteria & Skor \\
\hline Sangat Setuju & 4 \\
\hline Setuju & 3 \\
\hline Tidak Setuju & 2 \\
\hline Sangat Tidak Setuju & 1 \\
\hline
\end{tabular}

(Sumber: Riduwan, 2015: 228)

Selanjutnya dilakukan perhitungan dengan rumus:

$$
\bar{x}=\frac{\sum_{i}^{n}=1 x i}{n}
$$

Dengan:

$$
\bar{x}=\frac{\text { jumlah semua skor }}{4 \text { skor maksimum }} \times 100
$$

Keterangan:
$x$
Rata-rata akhir
$x i \quad$ Nilai uji operasional angke tiap mahasiswa
$\mathrm{N} \quad$ Banyaknya mahasiswa yang mengisi angket 
Tabel 2. Kriteria Kevalidan E-Modul

\begin{tabular}{|c|c|c|}
\hline Interval Skor & Kriteria & Keterangan \\
\hline $3,26 \leq \mathrm{x} \leq 4,00$ & Valid & Tidak Revisi \\
\hline $2,51 \mathrm{x}<3,26$ & Cukup Valid & Revisi Sebagian \\
\hline $1,76 \leq \mathrm{x}<2,51$ & Kurang Valid & $\begin{array}{c}\text { Revisi Sebagian dan Pengkajian Ulang } \\
\text { Materi }\end{array}$ \\
\hline $1,00 \leq \mathrm{x}<1,76$ & Tidak Valid & Revisi Total \\
\hline
\end{tabular}

(Sumber: Riduwan, 2015:228)

E-modul yang dikembangkan memiliki nilai kevalidan yang baik, jika minimal kriteria kevalidan yang dicapai adalah valid.

2. Analisis Kelayakan

Langkah-langkah untuk menganalisis kepraktisan E-modul yang diperoleh dari angket respon siswa dan guru. Berdasarkan skor rata-rata yang diperoleh dari angket respon siswa dikategorikan sesuai kriteria yang dilihat pada tabel. Data yang terkumpul diproses dengan cara dijumlahkan, dibandingkan dengan jumlah yang diharapkan dan diperoleh persentase, atau dapat ditulis dengan rumus berikut:

$$
\bar{x}=\frac{\text { jumlah semua skor }}{4 \text { skor maksimum }} \times 100
$$

Tabel 3. Kriteria Kelayakan E-Modul

\begin{tabular}{|c|c|c|}
\hline Interval Skor & Kriteria & \multicolumn{1}{|c|}{ Keterangan } \\
\hline $3,26 \leq \mathrm{x} \leq 4,00$ & Layak & Tidak Revisi \\
\hline $2,51 \mathrm{x}<3,26$ & Cukup Layak & Revisi Sebagian \\
\hline $1,76 \leq \mathrm{x}<2,51$ & Kurang Layak & $\begin{array}{c}\text { Revisi Sebagian dan Pengkajian Ulang } \\
\text { Materi }\end{array}$ \\
\hline $1,00 \leq \mathrm{x}<1,76$ & Tidak Layak & Revisi Total \\
\hline
\end{tabular}

(Sumber: Riduwan, 2015:228)

E-modul yang dikembangkan memiliki nilai kepraktisan yang baik, jika minimal kriteria kepraktisan yang dicapai adalah layak.

\section{PEMBAHASAN}

Hasil merupakan bagian utama artikel ilmiah, berisi: hasil bersih tanpa proses analisis data, hasil pengujian hipotesis. Hasil dapat disajikan dengan table atau grafik, untuk memperjelas hasil secara verbal. 
Penelitian dan pengembangan yang dilakukan menghasilkan produk berupa EModul (Elektronik Modul) Berbasis Contextual Teaching Pada Pembelajaran Kelas V Sekolah Dasar. Pada prosedur penelitian dan pengembangan, bahan ajar berupa EModul (Elektronik Modul) Berbasis Contextual Teaching Pada Pembelajaran Kelas V Sekolah Dasar ini dikembangkan menggunakan metode research and depelopment (R\&D) dengan model pengembangan ADDIE. Adapun hasil penilaian validasi ahli kebahasan dapat dilihat pada tabel di bawah ini.

Tabel 3. Hasil Validasi Bahan Ajar E-Modul Berbasis Contextual Teaching

\begin{tabular}{|l|l|l|l|}
\hline Validator & Tahap 1 & Tahap 2 & Keterangan \\
\hline Ahli Materi & 2,72 & 3,70 & Valid \\
\hline Ahli Bahasa & 2,82 & 3,64 & Valid \\
\hline Ahli Media & 2,72 & 3,76 & Valid \\
\hline Jumlah & 8,26 & 11,1 & - \\
\hline Rata-Rata & $\mathbf{2 , 7 5}$ & $\mathbf{3 , 7 0}$ & Valid \\
\hline
\end{tabular}

Berdasarkan tabel 4.10 hasil dari validasi media, validasi materi dan validasi bahasa, maka bahan ajar E-Modul Berbasis Contextual Teaching didapatkan rata-rata 3,74 dengan kategori valid.

Penelitian ini bertujuan untuk mengetahui pengembangan E-Modul Berbasis Contextual Teaching Pada pembelajaran Kelas V SD. Hasil penelitian ini terdiri dari 9 ahli validasi yaitu ahli media, ahli materi, dan ahli bahasa. Berdasarkan hasil validasi yang dilakukan oleh 9 dosen Universitas PGRI Palembang didapatkan hasil bahan EModul Berbasis Contextual Teaching materi dinyatakan dengan kategori cukup valid tetapi perlu direvisi terlebih dahulu, setelah dilakukan revisi maka didapatkan hasil valid dan tidak perlu direvisi lagi. Validasi bahan ajar ini meliputi validasi materi, validasi bahasa, dan validasi media atau tampilan.

Berdasarkan hasil penilaian validasi tahap 1 oleh ahli materi diperoleh skor pada ahli pertamasebesar 44 dengan rata-rata sebesar 2,58, sedangkan skor pada ahli kedua sebesar 51 dengan rata- rata sebesar 3. Pada ahli ketiga diperoleh skor sebesar 44 dengan rata-rata sebesar 2,58. Pada tahap pertama perlu dilakukan revisi, sehingga dilakukan validasi pada tahap kedua. Berdasarkan hasil penilaian validasi tahap 2 oleh ahli materi diperoleh skor pada ahli pertama sebesar 64 dengan rata- rata sebesar 3,76, sedangkan skor pada ahli kedua sebesar 65 dengan rata-rata sebesar 3,82. Pada ahli 
ketiga diperoleh skor sebesar 60 dengan rata-rata sebesar 3,52. Dengan demikian, hasil penilaian validasi oleh ahli materi termasuk dalam kategori valid.

Selanjutnya, pada ahli bahasa aspek yang dinilai yaitu kebahasaan, lugas, komunikatif, dan penggunaan. Berdasarkan hasil penilaian validasi tahap 1 oleh ahli bahasa diperoleh skor pada ahli pertama sebesar 36 dengan rata-rata sebesar 2,4, sedangkan skor pada ahli kedua sebesar 52 dengan rata-rata sebesar 3,46. Pada ahli ketiga diperoleh skor sebesar 39 dengan rata-rata sebesar 2,26. Pada tahap pertama perlu dilakukan revisi, sehingga dilakukan validasi pada tahap kedua. Berdasarkan hasil penilaian validasi tahap 2 oleh ahli bahasa diperoleh skor pada ahli pertama sebesar 56 dengan rata-rata sebesar 3,73, sedangkan skor pada ahli kedua sebesar 52 dengan ratarata sebesar 3,46. Pada ahli ketiga diperoleh skor sebesar 56 dengan rata-rata sebesar 3,73. Dengan demikian, hasil penilaian validasi oleh ahli bahasa termasuk dalam kategorivalid.

Selanjutnya, pada ahli bahasa aspek yang dinilai yaitu tampilan desain layar, kemudahan penggunaan, konsisten, kemanfaatan, dan kegrafikan. Berdasarkan hasil penilaian validasi tahap 1 oleh ahli media diperoleh skor pada ahli pertama sebesar 61 dengan rata-rata sebesar 2,44, sedangkan skor pada ahli kedua sebesar 76 dengan ratarata sebesar 3,06. Pada ahli ketiga diperoleh skor sebesar 67 dengan rata-rata sebesar 2,68. Pada tahap pertama perlu dilakukan revisi, sehingga dilakukan validasi pada tahap kedua. Berdasarkan hasil penilaian validasi tahap 2 oleh ahli media diperoleh skor pada ahli pertama sebesar 100 dengan rata-rata sebesar 4, sedangkan skor pada ahli kedua sebesar 100 dengan rata-rata sebesar 4. Pada ahli ketiga diperoleh skor sebesar 82 dengan rata-rata sebesar 3,28. Dengan demikian, hasil penilaian validasi oleh ahli media termasuk dalam kategorivalid.

Dari hasil penilaian validator materi, bahasa, dan media diperoleh jumlah skor pada tahap kedua sebesar 11,1, dengan rata-rata sebesar 3,70. Dengan demikian, dapat disimpulkan bahwapengembangan E-modul berbasis Contextual Teaching pada pembelajaran kelas V Sekolah Dasar termasuk dalam kategori valid.

Selanjutnya dilakukan uji praktikalitas bahan ajar E-Modul berbasis Contextual Teaching kepada kelompok kecil atau small grup. Dari penilaian kelompok kecil didapatkan rata-rata nilai sebesar 3,69 yang termasuk dalam kategori layak. Selanjutnya, dilanjutkan pada tahap kelompok besar dan diperoleh rata-rata nilai 
sebesar 3,60 yang termasuk dalam kategori praktis. Dari hasil uji kelompok kecil dan uji kelompok besar, diperoleh rata-rata sebesar 3,645. Dengan demikian, dapat disimpulkan bahwa kelayakan E-modul berbasis Contextual Teaching pada pembelajaran kelas V Sekolah Dasar termasuk dalam kategorilayak.

Hasil penelitian ini membuktikan bahwa pengembangan E-Modul Berbasis Contextual Teaching Pada pembelajaran Kelas V SD termasuk dalam kategori valid. Hasil penelitian ini didukung oleh penelitian Fadilah (2021) yang menyatakan bahwa E-Modul berbasis Contextual teaching valid dan layak digunakan sebagai salah satu sumber belajar. Selanjutnya, hasil penelitian Aprianti (2015) juga menyatakan bahwa modul berbasis contextual teaching dapat digunakan untuk meningkatkan hasil belajar.

Selanjutnya, Sanjaya (2017:225) menjelaskan bahwa model pembelajaran Contekstual Teaching and Learning (CTL) adalah suatu model pembelajaran yang menekankan pada proses keterlibatan peserta didik untuk dapat menerapkan kehidupan sehari-hari untuk meningkatkan proses pembelajaran peserta didik sekolah dasar kelas II. Andriyanti (2016) menyatakan bahwa dengan menggunakan model pembelajaran CTL dapat meningkatkan proses pembelajaran, aktivitas, dan hasil belajar siswa tingkat sekolah dasar. Selain itu, penelitian Ledy Ahrisya (2019) juga menyatakan bahwa model pembelajaran Contextual teaching and learning (CTL) mempengaruhi hasil belajar peserta didik kelas V Sekolah Dasar.

\section{SIMPULAN}

Berdasarkan hasil penelitian Pengembangan E-Modul Berbasis Contextual Teaching Pada Pembelajaran Kelas V Sekolah Dasar yang telah dilakukan, dapat disimpulkan bahwa. Hasil penilaian para ahli menunjukkan bahwa E-Modul Berbasis Contextual Teaching dengan rata-rata sebesar 3,70. Dengan demikian, dapat disimpulkan bahwa pengembangan E-modul berbasis Contextual Teaching pada pembelajaran kelas V Sekolah Dasar termasuk dalam kategori valid atau layak. Dari hasil uji kelompok kecil dan uji kelompok besar, diperoleh rata-rata sebesar 3,645. Dengan demikian, dapat disimpulkan bahwa kelayakan E-modul berbasis Contextual Teaching pada pembelajaran kelas V Sekolah Dasar termasuk dalam kategori praktis atau layak. 
Berdasarkan hasil penelitian pengembangan bahan ajar yang telah dijelaskan, bahan ajar ini masih memiliki banyak kelemahan. Oleh karena itu, beberapa hal dapat dijadikan saran sebagai berikut. Untuk guru, sebaiknya lebih sering menggunakan bahan ajar dan metode pembelajaran yang lebih menarik dan tidak membosankan dalam proses pembelajaran. Untuk sekolah, Melatih guru membuat bahan ajar sendiri. Untuk penelitian selanjutnya dapat dilakukan tahapan field test untuk mengetahui efektifitas bahan ajar yang telah dikembangkan.

\section{REFERENCES}

Andriyanti, Windy. (2016). Model Contextual Teaching and Learning Dalam Pembelajaran Menulis Permulaan Di Kelas II Sekolah Dasar. Jurnal cakrawala pendas, vol 2,84.

Aditama. Kuntarto, E. (2017). Kefektifan Model Pembelajaran Daring dalam Perkuliahan Bahasa Indonesia Perguruan Tinggi . Indonesian Language Education and Literature,10.24235/ileal.v3i1.1820, 99- 110.

Aprida Pane, M. D. (2017). Belajar dan Pembelajaran. Jurnal Kajian Ilmu-Ilmu Keislaman, 338.

Aprianti, Rika. (2015). Pengembangan E-Modul Berbasis Contextual Teaching and Learning (CTL) Dilengkapi Dengan Media Audio-Visual Untuk Meningkatkan Hasil Belajar Fisika Peserta Didik. E- Journal Vol 4, 137.

Ahrisya, Ledy. (2019). Pengaruh Model Pembelajaran Contextual Teaching and Learning (CTL) Terhadap Hasil Belajar Siswa Kelas V pada tema 9 subtema 1 di MI YPSM Al Manaar. E- Journal, vol 4, 338.

Daryanto. (2013). Menyusun Modul. Yogyakarta: Gava Media.

Depdiknas. (2008). Panduan Pengembangan Bahan Ajar. Jakarta: Direktorat Jendral Pendidikan Dasar dan Menengah.

Depdiknas. (2003). Pendekatan Kontekstual (Contextual Teaching and Learning CTL). Jakarta: Ditjen Dikdasmen.

Enriques, M. (2018). Students Perception On The Effectiveness of the Use of Edmodoasa Supplementary Tool for Learning. DLSU Research Congress. 
Fausih, M. (2019). Pengembangan Media E-modul Mata Pelajaran Produktif Pokok Bahasan instalasi jaringan LAN (Local Area Network)' untuk siswa kelas XI Jurusan Teknik Komputer Jaringan di SMK Negeri 1 Labang Bangkalan Madura. J. Mhs. Teknol. Pendidik.,vol.5, 0.3 , 190.

Hamdani. (2010). Strategi Belajar Mengajar. Bandung: Pustaka Setia.

Herawati, S.N., \& Muhtadi, A. 2018. Pengembangan Modul Elektronik (E-Modul) Interaktif Pada Mata Pelajaran Kimia Kelas XI SMA. Jural Inovasi Teknologi Pendidikan. 5(2).

Hidayah, Nurul. (2019). Pembelajaran Tematik Integratif di Sekolah Dasar. Jurnal Terampil: Keguruan dan Ilmu Tarbiyah, 36-37.

Kokom, K. (2013). Pembelajaran Kontekstual Konsep dan Aplikasi. Bandung: Reflika

Lefudin. (2014). Belajar dan Pembelajaran. Yogyakarta: Grup Penerbitan CV Budi

Utama. Majid, A. (2013). Perencanaan Pembelajaran. Bandung: PT Remaja Rosda Karya.

Murtono. (2017). Merencanakan dan Mengelola Model-Model Pembelajaran Inovatif. Ponorogo: Wade Group.

Mustaji. (2008). Pembelajaran Mnadiri. Surabaya: Unesa FIP.

Nurfadhilah, N. \&. (2018). Kemampuan Penalaran Matematis Melalui Pembelajaran Contextual Teaching and Learning pada siswa SMP. Jurnal Elemen, vol 4(2), 171.

Nurul Latifah, A. E. (2020). Pengembangan E-Modul Fisika Untuk Meningkatkan Kemampuan Berpikir Kritis Peserta Didik. JIPS:Jurnal Inovasi Pendidikan Sains, Vol.1 no.1 , 1-7.

Prastowo, A. (2011). Panduan Kreatif Membuat Bahan Ajar Inovatif.

Yogyakarta:

DIVA Pres. Purwanto, dkk. (2007). Pengembangan Modul. Jakarta: PUSTEKKOM Depdiknas.

Riduwan. (2015). Dasar-Dasar Statistik. Bandung: Alfabeta.

Riyana. (2012). Media Pembelajaran. Jakarta: Direktorat Jenderal Pendidikan Islam Kementrian Agama RI. 
Rusman, D. (2013). Model-model Pembelajaran Mengembangkan Profesionalisme

Guru. Jakarta: Rajawali Pers.

Sanjaya, W. (2006). Strategi Pembelajaran Berorientasi Standar Proses Pendidikan. Jakarta:

Kencana. Soimin, A. (2014). Model Pembelajaran Inovatif Dalam Kurikulum 2013.

Yogyakarta: Ar-Ruz Media. Solikin, Imam. (2019). Pengembangan Fitur

Notifikasi e-modul Pada Program Studi Manajemen Informatika. Jurnal SIMETRIS, Vol. 10 No.1 , 190.

Sugiyono. (2016). Metode Penelitian Kuantitatif, Kualitatif, dan R\&D. Bandung: Alfabeta.

Sugiyono. (2019). Metode Penelitian Pendidikan (Kuantitatif, Kualittif, Kombinasi, $R \& D$ dan Penelitian Pendidikan. Bandung: Alfabeta. . (2009). Mendesain Model Pembelajaran Inovatif-Progresif. Jakarta:

Kencana.

Zain, S. B. (2006). Strategi Belajar Mengajar. Jakarta: Rineka Cipta. 